\title{
Extract of Yerba Mate (Ilex paraguariensis A. St.-Hil., Aquifoliaceae) Improves the Weight Gain of Growing Quails
}

\section{Extrato de Erva-Mate (Ilex paraguariensis A. St.-Hil., Aquifoliaceae) Melhora o Ganho de Peso de Codornas em Crescimento}

\author{
Maira Rodrigues Dourado*a; Andreia Assunção Soares ${ }^{\mathrm{b}}$; Ricardo de Melo Germano ${ }^{\mathrm{b}}$; Izabela Camilotti Dorneles ${ }^{\mathrm{b}}$; \\ André Felipe Berto de Almada ${ }^{\mathrm{b}}$; Isabel Cristina da Silva Caetano ${ }^{\mathrm{b}}$; José Matheus Beltramib; Lucas de Almeida Reatia; \\ Euclides Lara Cardozo Júnior ${ }^{c}$; Taniara Suelen Mezalira ${ }^{\mathrm{b}}$; Aguinaldo Yoshio Nakamura ${ }^{\mathrm{b}}$; Luciana Kazue Otutumi ${ }^{\mathrm{b}}$ \\ ${ }^{a}$ Universidade Paranaense. PR, Brasil. \\ bUniversidade Paranaense, Programa de Pós-Graduação Stricto Sensu em Ciência Animal. PR, Brasil. \\ 'SUSTENTEC. PR, Brasil. \\ *E-mail: mairadourado_ta@hotmail.com
}

\begin{abstract}
The production of quail has expanded in Brazil, due to its low cost, rusticity and precocity. Using of yerba mate extract, due to its antiinflammatory, antioxidant and antimicrobial properties can be important in quail production. The aim of this study was to evaluate the effect of yerba mate supplementation on quail diet in relation to zootechnical performance, intestinal morphometry, antioxidant capacity and heterophile: lymphocyte ratio. 240 laying quails were randomly distributed in four treatments with different levels of yerba mate extract $(0,250,500$ and $1000 \mathrm{ppm}$ ), with four replicates of 15 birds each by 34 days. The performance ( 1 to 34 days of age), intestinal morphometry ( 7 and 34 days of age), plasma antioxidant capacity (34 days of age), and heterophile: lymphocyte ratio (34 days of age) were evaluated. Higher feed intake and weight gain were observed at the period from one to 34 days for the group treated with $1000 \mathrm{ppm}$ of yerba mate extract. However, the feed conversion, plasma antioxidant capacity, intestinal morphometry and heterophile: lymphocyte ratio did not differ among the different levels of yerba mate extract. It can be concluded that quails which received $1000 \mathrm{ppm}$ of yerba mate extract had higher weight gain, besides, others studies are needed to evaluate their effect on egg production and in animals genetically directed to weight gain, such as the meat-type lines.
\end{abstract}

Keywords: Villum Height. Coturnix Coturnix Japonica. Feed Conversion. Zootechnical Performance.

\section{Resumo}

A produção de codornas tem se expandido no Brasil, devido ao seu baixo custo, rusticidade e precocidade. O uso do extrato de erva-mate, devido à sua propriedade anti-inflamatória, antioxidante e antimicrobiana pode ser importante na produção de codornas. Dessa forma, o objetivo desse trabalho, foi avaliar o efeito da suplementação de erva-mate na dieta de codornas em relação ao desempenho zootécnico, morfometria intestinal, capacidade antioxidante e relação heterofilo: linfócito. 240 codornas de postura foram distribuídas aleatoriamente em quatro tratamentos com diferentes níveis do extrato de erva-mate (0, 250, 500 e 1000 ppm), com quatro repetições de 15 aves cada por 34 dias. Foram avaliados o desempenho (1 a 34 dias de idade), a morfometria intestinal (7 e 34 dias de idade), a capacidade antioxidante do plasma (34 dias de idade) e a relação heterofilo: linfócito (34 dias de idade). Um maior consumo de ração e ganho de peso foram observados para o periodo de um a 34 dias para o grupo tratado com 1000 ppm do extrato de erva-mate. Entretanto, a conversão alimentar, capacidade antioxidante do plasma, morfometria intestinal e relação heterofilo: linfócito não diferiram entre os diferentes níveis do extrato de erva-mate. Conclui-se que as codornas que receberam 1000 ppm do extrato de erva-mate apresentam maior ganho de peso, por outro lado, outros estudos são necessários, visando avaliar seu efeito na produção de ovos e em animais com genética direcionada para ganho de peso, tais como as linhagens especificas para corte.

Palavras-chave: Altura de Vilo. Coturnix Coturnix Japônica. Conversão Alimentar. Desempenho Zootécnico.

\section{Introduction}

Coturniculture is a promising activity in Brazil, and have evolved from a rustic to a technified activity. It was introduced in Brazil during the 60's and had a growing demand due to an increase in egg consumption. In addition, the characteristics of quail, including growth, sexual precocity and high productivity (PASTORE et al., 2012; BEEFPOINT, 2015), made the activity promising. However, to improve the zootechnical performance of the activity, several studies have been carried out, including those focusing on variations in the feed formulation (CASTIBLANCO, 2017).

There are several quails lineages, some more specific for slaughter and others for the eggs production. Quails of the species Coturnix coturnix are used for meat production because they present a notable weight gain, arriving at 200 g by 21 days, besides its meat is tastier than others meats. Another important species is Coturnix coturnix japonica, it has been mainly used by egg production for the fact it can reach 300 eggs/year (OLIVEIRA, 2014).

The yerba mate Ilex paraguariensis (A. St.-Hil.) extract is rich in bioactive compounds that are beneficial to health, such as methylxanthines, saponins, minerals, vitamins, and phenolic compounds (CAMARGO et al., 2011). The presence of phenolic compounds, derived from caffeoylquinic and flavonoid acids, give this species antioxidant and antiinflammatory properties (RIBANI, 2006). De Bona et al. (2010) carried out a study and they concluded that the extract of yerba mate also has antimicrobial properties, this can be 
attributed to its chemical composition. It can be considered that even though pathogenic microorganisms, such as Salmonella spp., can contribute for the sanitary challenge in broiler farms, they are also a problem to public health, and the use of the yerba mate extract can be an important aid in minimizing risks to health.

This work aimed to evaluate the effects of the supplementation with different concentrations of yerba mate extract $(0,250,500$, and $1000 \mathrm{ppm})$ on the growing quails rations in the zootechnical performance (feed intake, weight gain, and feed conversion), intestinal morphometry, heterophile:lymphocyte blood ratio, and plasma antioxidant capacity, due its anti-inflammatory and antimicrobial properties, which may increase the animals' performance.

\section{Material and Methods}

The experiment was carried out in the Experimental Aviary of the Veterinary Hospital of Universidade Paranaense, Umuarama, located in the Northwest region of Paraná (2346’00”.19S; 5316’26”.39W), after approval from the Ethics and Research Committee Involving Animal Experimentation of Universidade Paranaense under protocol $31446 / 2017$.

A total of 240 laying quails (Coturnix coturnix japonica) were used for an experimental period of 34 days, during the growing period. Quails were distributed into a completely randomized design with four treatments: $T_{1}=$ control treatment: no dietary supplementation of dried yerba mate extract; $\mathrm{T}_{2}=$ test treatment: diet supplemented with 250 ppm of dried yerba mate extract; $\mathrm{T}_{3}=$ test treatment: diet supplemented with 500 ppm of dried yerba mate extract; and $\mathrm{T}_{4}=$ test treatment: diet supplemented with $1000 \mathrm{ppm}$ of dried yerba mate extract. Each treatment had 4 replicates of 15 birds each, totaling 16 experimental units.

The raw vegetable material for the experiment was obtained from commercial crops of Ilex paraguariensis. Leaves were toasted in a rotary cylinder $\left(350\right.$ to $\left.400{ }^{\circ} \mathrm{C}\right)$, and following dried on a conveyor with a temperature from 90 to $100{ }^{\circ} \mathrm{C}$, then ground and packed. Extracts were obtained using the industrial spray drying process, carried out by the company DOMANI Produtos Naturais in Pato Bragado/PR.

The preparation of the extracts began with the grinding of the leaves and sieving to adjust the granulometry to \pm 6 $\mathrm{mm}$. The extracts underwent the aqueous extraction process at $85^{\circ} \mathrm{C}(1: 10 \mathrm{~m} / \mathrm{v})$ for 40 minutes under agitation, and were then centrifuged to separate the solid and liquid wastes. Subsequently, the concentration (Multi-Tubular Evaporator Concentrator Mod. JAA-INC 220 - Incal Machines) was carried out for six hours, with a temperature of $40{ }^{\circ} \mathrm{C}$ and pressure of $680 \mathrm{mmHg}$. The extracts were then dried in a spray dryer (Mod.SD-250- REMID) with an inlet and outlet temperatures of 240 and $60{ }^{\circ} \mathrm{C}$, respectively. The obtained dry extract was sent for final product packaging and subsequent determination of the total phenolic compounds and methylxanthines content (CARDOZO JUNIOR et al., 2007; MEINHART et al., 2010).

The birds were housed in a floor pens in a conventional poultry house covered with ceramic roof tiles, which were composed of 16 boxes of $2.775 \mathrm{~m}^{2}(1.85 \times 1.5 \mathrm{~m})$, where each box was allocated a feeder and a drinking fountain. The rations (Table 1) were formulated according to the feed chemical composition and nutritional requirements outlined by Rostagno et al. (2017).

Table 1 - Centesimal and nutritional composition of the experimental rations for growing quail for the stages of 1 to 14 and 15 to 34 days of age

\begin{tabular}{|c|c|c|}
\hline Ingredient & \multicolumn{2}{|c|}{ Centesimal Composition (\%) } \\
\hline & 1 to 14 days old & 15 to 34 days old \\
\hline Corn & 56.09 & 60.41 \\
\hline Soybean meal & 38.14 & 35.42 \\
\hline Dicalcium phosphate & 2.07 & 1.63 \\
\hline Calcitic limestone & 1.26 & 1.08 \\
\hline Salt & 0.46 & 0.48 \\
\hline $\begin{array}{l}\text { Premixed vitamins and } \\
\text { minerals * }\end{array}$ & 0.50 & 0.50 \\
\hline Inert & 0.20 & 0.20 \\
\hline Soy oil & 1.15 & 0.17 \\
\hline DL-methionine & 0.13 & 0.10 \\
\hline L-threonine & -- & 0.01 \\
\hline \multirow[t]{2}{*}{ Total } & 100.00 & 100.00 \\
\hline & \multicolumn{2}{|c|}{ Nutritional Composition } \\
\hline $\begin{array}{l}\text { Metabolizable energy } \\
(\mathrm{kcal} / \mathrm{kg})\end{array}$ & 2.900 & 2.900 \\
\hline Crude protein $(\%)$ & 22.14 & 21.27 \\
\hline Total calcium $(\%)$ & 1.09 & 0.91 \\
\hline Sodium $(\%)$ & 0.20 & 0.21 \\
\hline $\begin{array}{l}\text { Available phosphorus } \\
(\%)\end{array}$ & 0.51 & 0.43 \\
\hline Digestible lysine (\%) & 1.09 & 1.03 \\
\hline $\begin{array}{l}\text { Digestible methionine }+ \\
\text { cystine }(\%)\end{array}$ & 0.74 & 0.69 \\
\hline $\begin{array}{l}\text { Digestible tryptophan } \\
(\%)\end{array}$ & 0.25 & 0.24 \\
\hline Digestible threonine $(\%)$ & 0.75 & 0.73 \\
\hline
\end{tabular}

* Levels of guarantee Premix Tectron ${ }^{\circledast}$ : Methionine (min.) $400 \mathrm{~g} / \mathrm{kg}$; vitamin A (min.) 1,500,000 IU/kg; vitamin D3 (min.) 400,000 IU/kg; vitamin E (min.) 1,500 IU/g; vitamin K3 (min) $300 \mathrm{mg} / \mathrm{kg}$; vitamin B1 (min.) $270 \mathrm{mg} / \mathrm{kg}$; vitamin B2 (min.) $810 \mathrm{mg} / \mathrm{kg}$; vitamin B6 (min.) 480 $\mathrm{mg} / \mathrm{kg}$; vitamin B12 (min.) 1,500 mcg/kg; niacin (min.) 4,200 mg/kg; pantothenic acid (min.) $1,500 \mathrm{mg} / \mathrm{kg}$; folic acid (min.) $75 \mathrm{mg} / \mathrm{kg}$; biotin (min.) $18,75 \mathrm{mg} / \mathrm{kg}$; choline (min.) $74,25 \mathrm{mg} / \mathrm{kg}$; manganese (min.) $25 \mathrm{~g} /$ $\mathrm{kg}$; zinc (min.) $20 \mathrm{~g} / \mathrm{kg}$; iron (min.) 12,5 g/kg; copper (min.) 2,000 mg/kg; iodine (min.) $187 \mathrm{mg} / \mathrm{kg}$; and selenium (min.) $75 \mathrm{mg} / \mathrm{kg}$.

Source: Survey data.

The performance was evaluated through the determination of the weight gain $(\mathrm{g})$, feed intake $(\mathrm{g})$, and feed conversion $(\mathrm{g} / \mathrm{g})$, for which the birds were weighed weekly. The mean weight gain (WG) was determined by the difference between the final and initial weights of each experimental unit. The feed intake (FI) was determined by the difference between the feed provided and the leftovers in the buckets/feeders. 
The feed conversion (FC) was determined by the relationship between the feed consumption and weight gain of the birds.

At seven days of age and at the end of the experimental period, one bird from each experimental unit was randomly chosen to evaluate the intestinal morphometry of the jejunum. The animals were euthanized through the use of an intramuscularly (IM) administered anesthetic overdose of xylazine hydrochloride (Ceva Saúde Animal, Paulínia, $\mathrm{SP}$ ) - $4 \mathrm{mg} / \mathrm{kg}$ - and an intravenously (IV) administered overdose of thiopental sodium (Cristália, Itapira, SP) - 25 $\mathrm{mg} / \mathrm{kg}$. Then, a 2-cmsegment of the jejunum (prior to the Meckel's diverticulum) of each bird was submitted to routine histological techniques. The samples were washed with saline solution to remove all the intestinal contents and fixed in a buffered formalin solution for 24 hours. Semi-serialized cross-sections with a thickness of five $\mu \mathrm{m}$ were stained with hematoxylin and eosin (HE), to measure the villus height, crypt depth, and villus: crypt relationship. Images were obtained by means of a digital camera coupled to a trinocular light microscope with 10x objective, connected to an image analysis system for the posterior measurements of 60 villi and 60 crypts of each animal.

At the end of the experimental period, blood samples were collected from one bird per experimental unit, making a total of 16 samples. The blood samples were used for counting the heterophiles and lymphocytes, determining the heterophile: lymphocyte ratio, and ascertaining the total antioxidant capacity (FRAP assay - iron reduction).

The blood used to make the slides for the heterophile and lymphocyte counting was described in the methodology of Campo and Davila (2002). The FRAP assay was performed according to Benzie and Strain (1996) and Pulido et al. (2000).

For the statistical analysis, the parameters were first analyzed for their normality (Kolmogorov-Smirnov test) and homogeneity of variance (Levene's test). After confirming the data normality and homogeneity of variance, the parameters were submitted to an analysis of variance (ANOVA). When appropriate, the Tukey test was used to compare the means, after identifying the significant differences among the treatments in an ANOVA. The statistical program used was IBM SPSS v. 21.0. For all tests, a significance level of 5\% was used.

\section{Results and Discussion}

During the experimental period, the maximum environmental temperature obtained was $29.3{ }^{\circ} \mathrm{C}$ and the minimum $25.5^{\circ} \mathrm{C}$ and the relative humidity was $61.9 \%$.

The total phenolics content in the dried extract of yerba mate, determined using the Folin-Ciocalteu method, was $422.90 \mathrm{mg} / \mathrm{g}$, an equivalent of 5-CQA (5-o-caffeoylquinic acid). The Folin-Ciocalteu method is less specific, due to the fact that this method quantifies all compound with reductor activity. The methylxanthines were evaluated by determining the caffeine content in the dry extract, which was $44.27 \mathrm{mg} / \mathrm{g}$.
The rations of poultry usually have a high amount of fatty acids, which can lead to lipid oxidation. For this reason, synthetic antioxidants are used in the formulations. The extract of yerba mate, mainly associated with phenolic components, such as flavonoids, can minimize the adverse effects of lipid oxidation due to its high antioxidant potential (MARIUTTI; BRAGAGNOLO, 2009) and be used as an antioxidant in quail feed.

Among the phenolic compounds present in yerba mate are the flavonoids rutin and quercetin (HECK; DE MEJIA, 2007; CABRAL-MALHEIROS et al., 2010), caffeoylquinic acids, methylxanthines (CARDOZO JUNIOR et al., 2007), and triterpenic saponins (SUGIMOTO et al., 2009). In addition, Heck and De Mejia (2007) describe the presence of vitamins and minerals.

In the present study, the composition of total phenolics and caffeine of the yerba mate extract was analyzed. It was verified that the extract of yerba mate has a large amount of these compounds $(422.90 \mathrm{mg} / \mathrm{g})$, which have been widely studied due to their antioxidant capacity. According to Cardozo Junior et al. (2007), methylxanthines are also present in yerba mate, the main compound of this group is caffeine.

Considering the performance parameters, it was verified that there was a lower weight gain in the control group when compared to the other treatments that received different levels of dry yerba mate supplementation $(0,250,500$, and 1000 ppm) in the diet during the period from 1 to 14 days of age (Table 2). However, in the period from 14 to 34 days of age, it was verified that there was less feed intake by the animals of the control group when compared to the animals that received $1000 \mathrm{ppm}$ of yerba mate extract. In the total rearing period (1 to 34 days of age), there was a lower feed intake of the control group in relation to the other treatments. As for the weight gain, there was only difference between the control group and the group that received $1000 \mathrm{ppm}$ of the yerba mate extract (Table 2).

Table 2 - Means of feed intake (g), weight gain (g), and feed conversion $(\mathrm{g} / \mathrm{g})$ of laying quails, receiving different levels of dietary yerba mate extract $(0,250,500$, and $1000 \mathrm{ppm})$, from 1 to 14 days of age, 14 to 34 days of age, and 1 to 34 days of age

\begin{tabular}{|c|c|c|c|}
\hline Treatments & $\begin{array}{c}\text { Feed Intake } \\
(\mathbf{g})\end{array}$ & $\begin{array}{c}\text { Weight Gain } \\
(\mathbf{g})\end{array}$ & $\begin{array}{c}\text { Feed Conversion } \\
(\mathbf{g} / \mathbf{g})\end{array}$ \\
\hline & \multicolumn{3}{|c|}{1 to 14 days of age } \\
\hline Control & 77.53 & $31.42^{b}$ & 2.46 \\
\hline $250 \mathrm{ppm}$ & 102.21 & $44.98^{a}$ & 2.27 \\
\hline $500 \mathrm{ppm}$ & 97.10 & $44.18^{a}$ & 2.20 \\
\hline $1000 \mathrm{ppm}$ & 108.19 & $45.92^{a}$ & 2.35 \\
\hline SE & 6.29 & 0.97 & 0.1238 \\
\hline P-value & 0.0545 & $<0.01$ & 0.9777 \\
\hline & \multicolumn{3}{|c|}{14 to 34 days of age } \\
\hline Control & $268.83^{b}$ & 77.88 & 3.45 \\
\hline $250 \mathrm{ppm}$ & $289.71^{a b}$ & 76.99 & 3.76 \\
\hline $500 \mathrm{ppm}$ & $289.48^{a b}$ & 76.36 & 3.80 \\
\hline $1000 \mathrm{ppm}$ & $305.91^{a}$ & 78.05 & 3.96 \\
\hline SE & 5.76 & 2.52 & 0.13 \\
\hline
\end{tabular}




\begin{tabular}{|c|c|c|c|}
\hline P-value & 0.012 & 0.9777 & 0.2283 \\
\hline & \multicolumn{3}{|c|}{1 to 34 days of age } \\
\hline Control & $346.36^{b}$ & $109.30^{a}$ & 3.17 \\
\hline $250 \mathrm{ppm}$ & $391.92^{a}$ & $121.97^{a b}$ & 3.21 \\
\hline $500 \mathrm{ppm}$ & $386.58^{a}$ & $120.54^{a b}$ & 3.21 \\
\hline $1000 \mathrm{ppm}$ & $414.10^{a}$ & $124.00^{b}$ & 3.35 \\
\hline SE & 7.64 & 2.44 & 0.093 \\
\hline P-value & 0.05 & 0.032 & 0.5805 \\
\hline
\end{tabular}

$\mathrm{SE}=$ Mean standard error. Means followed by different letters in the column differ according to the Tukey test.

Source: Survey data.

Migotto (2015) evaluated the performance and nutrient digestibility of broilers fed diets containing different concentrations (250 to $1000 \mathrm{ppm}$ ) of yerba mate (Ilex paraguariensis), but he did not observe any effects on the performance (weight gain, feed intake, and feed conversion) or nutrient digestibility (dry matter, crude protein, ethereal extract, and crude energy). When comparing these results with those obtained in the present study, where the analyzed animal species differs, an improvement in the weight gain of the animals that received the feed supplemented with the yerba mate extract can be verified, presenting a greater gain in relation to the control group in the period from 1 to 34 days of age (Table 2).

In a study conducted by De Bona et al. (2010), the yerba mate extract proved to be efficient when inhibiting serovars of Salmonella spp. isolated from in vitro broilers, with the extract presenting bacteriostatic and bactericidal properties at levels of 150 and $200 \mathrm{ppm}$. It should be noted that in the present study, the effects of the yerba mate extract in relation to its bacteriostatic and bactericidal capacities were not evaluated. However, the results of De Bona et al. (2010) support the outcomes of the present study in relation to performance, since there was greater weight gain for the animals that received the yerba mate extract. This can be justified by the control of the enterobacteria present in the digestive system, because according to Back and Ishizuka (2010), enterobacteria colonize the respective system and could aid in performance improvements.

Freitas et al. (2012) evaluated the use of an antioxidant from the extract of the stone and skin of the mango (Mangifera $s p$. L.) at a dosage of 200 and $400 \mathrm{ppm}$ added to the broiler rations. When evaluating the feed intake, weight gain, and feed conversion from 1 to 42 days of age, the authors observed that there was no significant difference between the control group and the group with the addition of the synthetic antioxidant butylated hydroxytoluene (BHT). However, in the same study, the mango stone extract (at dosages of 200 and $400 \mathrm{ppm}$ ) delayed the lipid oxidation of the chicken breast meat, evaluated through the determination of the reaction of substances to thiobarbituric acid (TBARS), showing the antioxidant capacity of extracts rich in phenolic compounds.

Despite the quail rusticity and precocity (Coturnix coturnix japonica), those animals presented higher feed conversion when compared to broilers lines of high weight gain, however, the results in this work are close to those obtained by Ustundag and Ozdogan (2019) that evaluated Japanese quails from zero to 35 days of age (mean $2.99 \mathrm{~g} / \mathrm{g}$ ).

In relation to the antioxidant capacity of the plasma (FRAP), there were no significant differences among the treatments (control, 250, 500, and $1000 \mathrm{ppm}$ ) of yerba mate extract (Table 3).

Table 3 - Total antioxidant capacity (reduced iron) of the plasma of laying quails, receiving diets with various levels $(0,250,500$, and $1000 \mathrm{ppm}$ ) of yerba mate extract, measured using the FRAP assay (Trolox equivalent $\mathrm{mmol} / \mathrm{ml}$ ).

\begin{tabular}{|l|c|}
\hline Treatment & MmoL Trolox equivalent/mL \\
\hline Control & $70.25 \pm 3.46$ \\
\hline $250 \mathrm{ppm}$ yerba mate extract & $67.12 \pm 6.08$ \\
\hline $500 \mathrm{ppm}$ yerba mate extract & $61.91 \pm 0.81$ \\
\hline $1000 \mathrm{ppm}$ yerba mate extract & $70.24 \pm 4.76$ \\
\hline CV\% & 10.71 \\
\hline
\end{tabular}

Mean \pm standard error; $\mathrm{CV} \%$ : coefficient of variation.

Source: Survey data.

Oxidation is responsible for undesirable changes in the meat of animals intended for consumption, such as changes in the color, taste, and aroma. In addition, lipid oxidation may give rise to compounds harmful to consumer health and compromise the food shelf life (RAMALHO; JORGE, 2006). There are several methods for analyzing the oxidation and antioxidant effects of a product, such as the FRAP method, which involves iron ion reduction analysis (URREAVICTORIA et al., 2016). In the present work, the antioxidant capacity of the yerba mate extract was evaluated according to the methods of Benzie and Strain (1996). According to the analysis, there were no significant differences in the antioxidant capacity of the extract in the different treatments (Table 3).

According to Yeum et al. (2004) and Vossem et al. (2011), hydrophilic antioxidant compounds are measured in this technique and due to the low supplementation dosage of the extract it was not possible to verify any significant differences in the antioxidant capacity of the plasma (FRAP) of the laying quails. However, it is important to note that the total antioxidant capacity (FRAP) is verified for all groups and the mechanism for the biological action is not well understood.

The supplementation of different levels of yerba mate extract did not change the total length of the intestine and small intestine at seven and 34 days of age (Table 4).

Table 4 - Means of the total $(\mathrm{cm})$ and small intestine lengths $(\mathrm{cm})$ of laying quails, receiving different levels of dietary yerba mate extract $(0,250,500$, and $1000 \mathrm{ppm})$, at 7 and 34 days of age

\begin{tabular}{|c|c|c|}
\hline Treatment & $\begin{array}{c}\text { Total length of } \\
\text { intestine (cm) }\end{array}$ & $\begin{array}{c}\text { Length of small } \\
\text { intestine (cm) }\end{array}$ \\
\hline & \multicolumn{2}{|c|}{7 days of age } \\
\hline Control & 28.25 & 25.75 \\
\hline $250 \mathrm{ppm}$ & 26.83 & 24.17 \\
\hline $500 \mathrm{ppm}$ & 25.75 & 23.25 \\
\hline $1000 \mathrm{ppm}$ & 28.12 & 26.75 \\
\hline
\end{tabular}




\begin{tabular}{|c|c|c|}
\hline SEM & 1.32 & 1.18 \\
\hline P value & 0.5672 & 0.263 \\
\hline & \multicolumn{2}{|c|}{34 days of age } \\
\hline Control & 40.67 & 34.67 \\
\hline $250 \mathrm{ppm}$ & 42.12 & 38.12 \\
\hline $500 \mathrm{ppm}$ & 43.12 & 39.75 \\
\hline $1000 \mathrm{ppm}$ & 43.50 & 39.37 \\
\hline SEM & 2.71 & 2.22 \\
\hline P value & 0.8941 & 0.5478 \\
\hline
\end{tabular}

SEM = Standard error of the mean. Not significant according to ANOVA. Source: Survey data.

The intestinal morphometry evaluated by using the means of the villus height, crypt depth, and villus: crypt ratio at 7 and 34 days of age did not show significant differences $(\mathrm{P}>0.05)$ among the treatments (Table 5).

Table 5 - Mean \pm standard error of the villus height (VH), crypt depth (CD), and villus: crypt ratio (VRC) of the jejunum of laying quails, receiving different levels of dietary yerba mate extract $(0$, 250, 500, and $1000 \mathrm{ppm}$ ), at 7 and 34 days of age

\begin{tabular}{|c|c|c|c|}
\hline \multirow{2}{*}{ Treatment } & $\mathbf{V H}(\mu \mathrm{m})$ & $\mathbf{C D}(\mu \mathrm{m})$ & VRC \\
\hline & \multicolumn{3}{|c|}{7 days of age } \\
\hline Control & $258.54 \pm 6.95$ & $57.66 \pm 2.04$ & $4.49 \pm 0.06$ \\
\hline $\begin{array}{c}250 \mathrm{ppm} \\
\text { yerba mate } \\
\text { extract }\end{array}$ & $313.19 \pm 26.09$ & $66.46 \pm 6.61$ & $4.74 \pm 0.13$ \\
\hline $\begin{array}{c}500 \mathrm{ppm} \\
\text { yerba mate } \\
\text { extract }\end{array}$ & $286.91 \pm 16.27$ & $57.69 \pm 2.40$ & $5.00 \pm 0.37$ \\
\hline $\begin{array}{c}1000 \mathrm{ppm} \\
\text { yerba mate } \\
\text { extract }\end{array}$ & $286.80 \pm 29.05$ & $56.78 \pm 6.15$ & $5.06 \pm 0.06$ \\
\hline \multirow[t]{2}{*}{$\mathrm{VC} \%$} & 13.41 & 14.24 & 6.35 \\
\hline & \multicolumn{3}{|c|}{34 days of age } \\
\hline Control & $355.71 \pm 44.93$ & $45.28 \pm 1.78$ & $7.82 \pm 0.78$ \\
\hline $\begin{array}{c}250 \mathrm{ppm} \\
\text { yerba mate } \\
\text { extract }\end{array}$ & $443.46 \pm 30.00$ & $46.90 \pm 2.25$ & $9.52 \pm 0.91$ \\
\hline $\begin{array}{c}500 \mathrm{ppm} \\
\text { yerba mate } \\
\text { extract }\end{array}$ & $358.93 \pm 29.33$ & $47.23 \pm 2.95$ & $7.58 \pm 0.24$ \\
\hline $\begin{array}{c}1000 \mathrm{ppm} \\
\text { yerba mate } \\
\text { extract }\end{array}$ & $317.85 \pm 20.08$ & $45.06 \pm 1.91$ & $7.06 \pm 0.37$ \\
\hline $\mathrm{VC} \%$ & 15.00 & 8.60 & 12.44 \\
\hline
\end{tabular}

Not significant according to ANOVA. VC: Variation coefficient.

Source: Survey data.

For an animal to have good performance results and for the diet provided to meet the animal's requirements, it is vitally important that the animal has good intestinal health, with its physiological characteristics suitable for it to absorb and take advantage of the available nutrients (MAIORKA, 2004). In this regard, evaluations such as the villus height and crypt depth are extremely important because they reflect the absorption capacity of the intestine, since the higher villus height and crypt depth, the greater the absorption capacity (OLIVEIRA, 2015). This will consequently improve the animal's zoothecnical performance. However, in the present work, there were no differences in the villus height or crypt depth of the jejunum of laying quails at 7 and 34 days of age as a result of the supplementation of the diet with yerba mate extract. This result may be associated with the fact that, in the present study, the animals were raised under adequate sanitary conditions, in which the birds showed no signs of respiratory or digestive damage and viability ranged from $83.3 \%$ to $95.8 \%$.

Oliveira (2015) evaluated the zootechnical performance of broiler chickens fed diets containing guava extract at different inclusion levels $(0,0.5,1.0$, and $1.5 \%)$ during the period from 1 to 21 days of age and did not find significant differences for the weight gain, feed intake, or feed conversion. In the same study, the villus height, crypt depth, and villus: crypt ratios of the duodenum, jejunum, and ileum were also evaluated at 21 days, and similarly to the present study there were no significant differences in the villus heights of the different treatments. However, a significant result was found for the villus: crypt ratio of the ileum at 21 days of age, where treatment with $1.5 \%$ inclusion had the highest ratio. The byproduct of guava has tannins, glucans, and phenols, it can avoid the propagation of oxidation reactions, mainly of lipids (OLIVEIRA, 2015), which is according with the yerba mate extract, that has an antioxidant effect and the presence of phenolic compounds and flavonoids (DE BONA et al., 2010; MIGOTTO, 2015).

Regarding the heterophile: lymphocyte ratio of the blood samples, no significant differences were found among the treatments (Table 6).

Table 6 - Heterophile: lymphocyte ratio of the blood of laying quails, receiving diets supplemented with different levels of yerba mate extract $(0,250,500$, and $1000 \mathrm{ppm})$, at 34 days of age

\begin{tabular}{|l|c|}
\hline Treatments & Heterophile: lymphocyte ratio \\
\hline Control & 0.39 \\
\hline $250 \mathrm{ppm}$ & 0.38 \\
\hline $500 \mathrm{ppm}$ & 0.39 \\
\hline $1000 \mathrm{ppm}$ & 0.27 \\
\hline SEM & 0.086 \\
\hline
\end{tabular}

Not significant according to ANOVA. SEM $=$ Standard error of the mean. Source: Survey data.

The heterophile:lymphocyte ratio is another very important evaluation in poultry rearing, since it serves as an indicator of chronic stress in the animal (KODAIRA et al., 2015). The elevation of the number of heterophiles can be indicative not only of stress, but also of inflammatory processes, infections (GONÇALVES, 2013), and the ability to produce oxygen free radicals, which affects the antioxidant capacity (TELL $e t$ al., 1997). However, in the present work no differences were observed in the heterophile: lymphocyte ratio, probably due to the fact that the laying quails were bred under adequate management conditions, and there were no stimuli for the differentiation of the heterophile: lymphocyte ratio. 


\section{Conclusion}

In conclusion, to meet the demand for animal protein consumption, the production of other sources of animal protein, such as quail eggs, have been expanded. In addition, the use of plant extracts with antioxidant potential, such as the extract of yerba mate, has been encouraged because it is a natural product that presents no health risks and there is a possibility of improving animal performance, due to the presence of phenolic compounds. However, although the results of the present study showed a greater weight gain for the quails that received 1000 ppm of yerba mate extract, when compared to the control group, further studies are necessary to evaluate the effects on egg production and animals with genetics directed to gain weight, such as the specific meattype lines.

\section{Acknowledgements}

The authors are grateful to DEGPP (Executive Management of Research and Graduate Management) of the University of Parana - UNIPAR for the finance granted and to the company DOMANI natural products for the donation of the dried extract of yerba mate. This study was financed in part by Coordenação de Aperfeiçoamento de Pessoal de Nível Superior - Brasil (CAPES) - Finance Code 001.

\section{References}

BACK, A.; ISHIZUKA, M.M. Principais doenças de notificação obrigatória da Organização Mundial de Saúde Animal. São Paulo: AGWM, 2010.

BEEFPOINT. Mapa: veja as projeções para o mercado de carnes brasileiro até 2025. 2015. Disponível em: https://www.beefpoint. com.br/mapa-veja-as-projecoes-para-o-mercado-de-carnesbrasileiro-ate-2025/ Acesso em: 18 set. 2019.

BENZIE, I.F.F.; STRAIN, J.J. The ferric reducing ability of plasma (FRAP) as a measure of "antioxidant power": the FRAP assay. Analytical Biochem., v.239, p.70-76, 1996. doi: 10.1006/ abio.1996.0292.

CABRAL-MALHEIROS, G. et al. O tempo e o tipo de embalagem sobre a erva-mate tipo chimarrão durante armazenagem em condições ambientais. Ciênc. Rural, v.40, n.3, p.654-660, 2010. doi: /10.1590/S0103-84782010005000028

CAMARGO, V.B. et al. Determinação de compostos fenólicos totais em amostras de erva-mate (Ilex paraguariensis, St. Hill.). In: SALÃO INTERNACIONAL DE ENSINO, PESQUISA E EXTENSÃO, 3., 2011, Bagé. Anais ... Bagé, Rio Grande do Sul, 2011.

CARDOZO JUNIOR, E.L. et al. Methylxanthines and phenolic compounds in mate (Ilex paraguariensis St. Hil.) progenies grown in Brazil. J. Food Composition Anal., v.20, n.7, p.553-558, 2007. doi: 10.1016/j.jfca.2007.04.007

CASTIBLANCO, D.M. C. Respostas de codornas em produção a diferentes níveis de energia na meta. 2017. Disponível em: https://repositorio.unesp.br/handle/11449/150575. Acesso em: 15 jun. 2019.

CAMPO, J.L.; DAVILA, S.G. Influence of mating ratio and group size on indicators of fearfulness and stress of hens and cocks. Poultry Scie., v.81, n.8, p.1099-1103, 2002. doi: 10.1093/ ps/81.8.1099

DE BONA, E.A.M. et al. Avaliação da atividade antimicrobiana de erva-Mate (Ilex paraguariensis) sobre sorovares de Salmonella spp. de origem avícola. Ciênc. Biol. Saúde, v.12, n.3, p.45-48, 2010.

FREITAS, E.R. et al. Extratos etanólicos da manga como antioxidantes para frangos de corte. Pesq. Agropec. Bras., v.47, n.8, p.1025-1030, 2012.

GONÇALVES, M.D.P. Prevalência de parasitismo por carraças e influência no estado de saúde de passeriformes. 2013. Disponível em: https://estudogeral.sib.uc.pt/handle/10316/24734. Acesso em: 10 jun. 2019.

HECK, C.I.; DE MEJIA, E.G. Yerba mate tea(Ilexparaguariensis): A comprehensive review on chemistry, health implications, and technological considerations. J. Food Scie., v.72, n.9, p.138-151, 2007. doi: $10.1111 / j .1750-3841.2007 .00535 . x$

KODAIRA, V. et al. Concentração de glicose sanguínea e relação heterófilo:linfócito podem ser utilizados como indicadores de estresse térmico para aves poedeiras? Braz. J. Biosystems Engineering, v.9, n.2, p.1-9, 2015. doi: http://dx.doi.org/10.18011/ bioeng2015v9n2p182-190

MAIORKA, A. Impacto da saúde intestinal na produtividade avícola. In: SIMPÓSIO BRASIL SUL DE AVICULTURA, 5., 2004, Chapecó: NUCLEOVET. Disponível em: http://www. cnpsa.embrapa.br/sgc/sgc_publicacoes/anais_V_bsa_Alex.pdf. Acesso em: 01. fev. 2019.

MARIUTTI, L.R.B.; BRAGAGNOLO, N. A oxidação lipídica em carne de frango e o impacto da adição de sálvia (Salvia officinalis, L.) e de alho (Allium sativum, L.) como antioxidantes naturais. Rev. Inst. Adolfo Lutz, v.68, n.1, p.1-11, 2009.

MEINHART, A.D. et al. Methylxanthines and phenolics content extracted during the consumption of mate (Ilex paraguariensis St. Hil) beverages. J. Agric. Food Chem., v.58, n.4, p.2188-2193, 2010. doi: $10.1021 / \mathrm{j} 903781 \mathrm{w}$.

MIGOTTO, D.L. Desempenho e digestibilidade de nutrientes para frangos de corte alimentados com rações contendo extrato de erva mate (Ilex paraguariensis). Brasília: Universidade de Brasília, 2015.

OLIVEIRA, A. Espécies de codornas: europeia, americana, japonesa, chinesa e africana. Centro de produções técnicas 2014. Disponível em: https://www.cpt.com.br/cursos-avicultura/ artigos/especies-de-codornas-europeia-americana-japonesachinesa-e-africana. Acesso em: 1 fev. 2019.

OLIVEIRA, M.D. Efeito antioxidante do subproduto da goiaba na dieta de frangos sobre o desempenho e qualidade de carne. Goiânia: Universidade Federal de Goiânia, 2015.

PASTORE, S.M.; OLIVEIRA, W.P.; MUNIZ, J.C.L. Panorama da coturnicultura no Brasil. Rev. Eletr. Nutr., v. 9, n.6, p.20412049, 2012.

PULIDO, R.; BRAVO, L.; SAURA-CALIXTO, F. Antioxidant activity of dietary polyphenols as determined by a modified ferric reducing/antioxidant power assay. J. Agric. Food Chem., v.48, n.8, p.3396-3402, 2000. doi: https://doi.org/10.1021/jf9913458.

RAMALHO, V.C.; JORGE, N. Antioxidantes utilizados em óleos, gorduras e alimentos gordurosos. Quím. Nova, v.29, n.4, p.755-760, 2006.

RIBANI, R.H. Compostos fenólicos em erva-mate e frutas. Campinas: Unicamp, 2006.

ROSTAGNO, H. S. et al. Tabelas brasileiras para aves e suínos: composição de alimentos e exigências nutricionais. Viçosa: UFV, 2017. 
SUGIMOTO, S. et al. Brazilian natural medicines. III. Structures of triterpene oligoglycosides and lipase inhibitors from mate, leaves of Ilex paraguariensis. Chem. Pharm. Bull.n, v.57, n.3, p.257-261, 2009.

URREA-VICTORIA, V. et al. Ensaio antioxidante em microplaca do poder de redução do ferro (FRAP) para extrato de algas. São Paulo: Instituto de Biociencias, 2016.

YEUM, K.J. et al. Biomarkers of antioxidant capacity in the hydrophilic and lipophilic compartments of human plasma. Arch. Biochem. Biophysics, v.430, n.1, p 97-103, 2004. doi: 10.1016/j. abb.2004.03.006
VOSSEM, E. et al. Effect of dietary antioxidant supplementation on the oxidative status of plasma in broilers. J. Anim. Phys. Anim. Nutr., v.95, n.2, p.1985-205, 2011. doi: 10.1111/j.14390396.2010.01041.x

TELL, L.A. et al. A technique for isolating heterophils from blood of oranged-winged Amazon parrots (Amazona amazonica amazonica). Comp. Haematol. Int., v.7, n.1, p.47-53, 1997.

USTUNDAG, A.O.; OZDOGAN, M. Effects of bacteriocin and organic acid on growth performance, small intestine histomorphology, and microbiology in Japanese quails (Coturnix coturnix japonica). Trop. Anim. Health Production, v.51, p.21872192, 2019. doi: 10.1007/s11250-019-01931-0 